\title{
Laccase purified from Cerrena unicolor exerts antitumor activity against leukemic cells
}

\author{
ANNA MATUSZEWSKA ${ }^{1 *}$, MARTA KARP $^{2,3 *}$, MAGDALENA JASZEK $^{1}$, \\ GRZEGORZ JANUSZ ${ }^{1}$, MONIKA OSIŃSKA-JAROSZUK ${ }^{1}$, JUSTYNA SULEJ ${ }^{1}$, \\ DAWID STEFANIUK ${ }^{1}$, WALDEMAR TOMCZAK ${ }^{4}$ and KRZYSZTOF GIANNOPOULOS ${ }^{2}$ \\ ${ }^{1}$ Department of Biochemistry, Maria Curie-Skłodowska University, Lublin 20-033; \\ ${ }^{2}$ Department of Experimental Hemato-Oncology, Medical University of Lublin, Lublin 20-093; \\ ${ }^{3}$ Postgraduate School of Molecular Medicine, Medical University of Warsaw, Warsaw 02-091; \\ ${ }^{4}$ Department of Hemato-Oncology and Bone Marrow Transplantation, Medical University of Lublin, Lublin 20-081, Poland
}

Received January 26, 2015; Accepted November 20, 2015

DOI: $10.3892 / \mathrm{ol} .2016 .4220$

\begin{abstract}
Chronic lymphocytic leukemia (CLL) is the most commonly observed adult hematological malignancy in Western countries. Despite the fact that recent improvements in CLL treatment have led to an increased percentage of complete remissions, CLL remains an incurable disease. Cerrena unicolor is a novel fungal source of highly active extracellular laccase (ex-LAC) that is currently used in industry. However, to the best of our knowledge, no reports regarding its anti-leukemic activity have been published thus far. In the present study, it was hypothesized that $C$. unicolor ex-LAC may possess cytotoxic activity against leukemic cell lines and CLL primary cells. C. unicolor ex-LAC was separated using anion exchange chromatography on diethylaminoethyl cellulose-Sepharose and Sephadex G-50 columns. The cytotoxic effects of ex-LAC upon 24- and 48-h treatment on HL-60, Jurkat, RPMI 8226 and K562 cell lines, as well as CLL primary cells of nine patients with CLL, were evaluated using 2,3-bis(2-methoxy-4-nitro-5-sulfophenyl)-2H-tetrazolium-5-carboxanilide (XTT) assay. Annexin V/propidium iodide staining of Jurkat cells treated with ex-LAC was used to investigate apoptosis via flow cytometry. Ex-LAC induced changes in Jurkat and RPMI 8226 cells, as visualized by fluorescence and scanning electron microscopy (SEM). The XTT assay revealed high cytotoxic rates following treatment with various concentrations of ex-LAC on all the cell lines and CLL primary
\end{abstract}

Correspondence to: Dr Anna Matuszewska, Department of Biochemistry, Maria Curie-Skłodowska University, 19 Akademicka, Lublin 20-033, Poland

E-mail: anna.matuszewska@umcs.lublin.pl

*Contributed equally

Key words: chronic lymphocytic leukemia, Cerrena unicolor, laccase, HL-60 human acute promyelocytic leukemia cells, Jurkat human T cell leukemia cells, RPMI 8226 human multiple myeloma cells, K562 human chronic myeloid leukemia in blast crisis cells cells analyzed, with a half maximal inhibitory concentration ranging from 0.4 to $1.1 \mu \mathrm{g} / \mathrm{ml}$. Fluorescence microscopy and SEM observations additionally revealed apoptotic changes in Jurkat and RPMI 8226 cells treated with ex-LAC, compared with control cells. These results were in agreement with the apoptosis analysis of Jurkat cells on flow cytometry. In conclusion, $C$. unicolor ex-LAC was able to significantly induce cell apoptosis, and may represent a novel therapeutic agent for the treatment of various hematological neoplasms.

\section{Introduction}

Chronic lymphocytic leukemia (CLL) is the most commonly observed hematological malignancy in Western countries (1-3). It represents $0.8 \%$ of all the neoplasms and almost $30 \%$ of all the leukemia cases documented worldwide (1-3). CLL affects particularly the elderly, since the median age at diagnosis is 72 years, although increased morbidity among younger patients has been recently reported (1-3). The incidence of CLL is 2-6 cases/100,000 patients/year, and it increases with age (1-3). The risk of malignancy development is double in men compared with women (1-3). CLL is a lymphoproliferative disorder that may be characterized by the accumulation of small, homogeneous, mature cluster of differentiation (CD) $5^{+}$CD19+ B-lymphocytes in the peripheral blood, bone marrow and secondary lymphoid organs $(3,4)$. The clinical course of CLL is diverse. Certain patients display a favorable course of disease, with stable or slowly increasing lymphocytosis, long survival and no requirement for treatment, whereas other patients experience an aggressive, progressive course of CLL that requires immediate intensive therapy $(3,4)$. The clinical heterogeneity observed in the course of CLL is due to genetic and epigenetic abnormalities (2-5). The microenvironment is additionally known to be involved in leukemogenesis (2-5). However, the pathological mechanism of CLL remains to be elucidated (2-5). Several prognostic factors have been described that are useful for risk stratification in CLL, including cytogenetic abnormalities (deletion of the chromosomes 11q and 17p), expression of CD38 and zeta-chain-associated protein kinase 70 , and mutation status 
in immunoglobulin heavy chain variable region genes (2-5). Recent improvements in CLL treatment have led to an increased percentage of complete remissions. However, due to the advanced age of the patients and/or the presence of negative markers, relapse is expected in the majority of cases (2-5). Hence, the requirement for the development of novel therapies for the treatment of CLL remains.

Medicinal mushrooms have been extensively used in oriental medicine as a remedy against various disorders, including malignancies (6). To the best of our knowledge, of all the known species of mushrooms, 650 possess documented medicinal properties, and $\sim 20$ are currently in clinical use (6). Genera of mushrooms displaying antineoplastic activity include Pleurotus, Phellinus, Ganoderma, Agaricus, Antrodia, Clitocybe, Cordyceps, Trametes, Calvatia, Xerocomus, Suillus, Schizophyllum, Flammulina, Funlia, Inonotus, Lactarius, Inocybe, Albatrellus, Fomes and Russula (6-8). Extracts from these mushrooms contain bioactive compounds, including proteins, polysaccharides, glycosides, fats, volatile oils, alkaloids, phenols, tocopherols, folates, carotenoids, flavonoids, organic acids and ascorbic acid enzymes (6-8). These extracts are able to inhibit mitosis and angiogenesis, induce apoptosis and restrain proliferation of neoplastic cells (6-8).

Laccase [benzenediol:oxygen oxidoreductase, enzyme commission number, 1.10.3.2 (http://www.kegg.jp/dbget-bin/ www_bget?ec:1.10.3.2); LAC] is part of the largest subgroup of blue multicopper oxidases, and exhibits the distinctive redox ability of copper ions, since it is capable of catalyzing the oxidation of an extensive range of aromatic substrates concomitantly with the reduction of molecular oxygen to water $(9,10)$. The distribution of LAC is widespread among plants, fungi and bacteria (7). In particular, white-rot fungi have been identified to be the most efficient LAC producers (7,11-13). Cerrena unicolor has been established as the most effective fungal source of extracellular (ex)-LAC, with the highest activity reported to be $60,000 \mathrm{nkat} / \mathrm{l}$ (14). C. unicolor ex-LAC has been utilized in biodegradation, bioremediation, delignification and decolorization, although no data regarding its anticancer activity have been published to date (15).

The present study aimed to investigate the in vitro cytotoxicity of $C$. unicolor ex-LAC against leukemic cells. CLL cells were used as a model of disease in order to examine novel therapeutic agents, since they consist of two compartments: i) an accumulation compartment in the peripheral blood, followed by the spleen and liver; and ii) a proliferation compartment in the lymph nodes and bone marrow (4). No transgenic model or cell line of CLL currently exists (4). Therefore, several hematological cell lines were used in the present study, in addition to primary CLL cells, to evaluate the cytotoxic activity of C. unicolor ex-LAC against leukemic cells.

\section{Materials and methods}

Strain, medium, growth processing and preliminary separation of ex-LAC. C. unicolor (Bull.ex.Fr.) Murr, No. 139, was acquired from the Regensburg Culture Collection, Archaea Centre, University of Regensburg (Regensburg, Germany) and deposited in the fungal collection at the Department of Biochemistry of Maria Curie-Skłodowska University (Lublin, Poland) under the strain no. 139 (internal transcribed spacer sequence deposited in the GenBank database under the accession no. DQ056858) (16). Fermenter scale cultivation was performed at $28^{\circ} \mathrm{C}$ in a BioFlo ${ }^{\circledR} 310$ fermenter (New Brunswick Scientific; Eppendorf, Hamburg, Germany) containing 21 Lindenberg and Holm medium (Sigma-Aldrich, St. Louis, MO, USA) sterilized at $121^{\circ} \mathrm{C}$ for $30 \mathrm{~min}$ (14). The fermenter was inoculated with crumbled fungal mats (10\% of total volume), aerated at $11 \mathrm{air} / \mathrm{min}$ and stirred at $100 \mathrm{rpm}$. Antifoam B emulsion (Sigma-Aldrich) was occasionally added to the fermenter cultures in order to disperse any foam formation. Cultures (10-day-old) were filtered through Miracloth (Calbiochem; EMD Millipore, Billerica, MA, USA) and utilized for subsequent assays. The beginning of the idiophase was determined according to the protocol recommended by Betina (17). The culture liquid obtained following mycelium separation was centrifuged (Sigma 4-16KS; SciQuip Ltd., Shropshire, UK) at $10,000 \times \mathrm{g}$ for $15 \mathrm{~min}$. The supernatant was subdivided into two fractions via ultrafiltration, using Ultracel-10 membranes (EMD Millipore) incorporated into Pellicon 2 Mini cassettes holders (EMD Millipore). The fraction containing substances of molecular weight $>10 \mathrm{kDa}$ was used as the source of crude ex-LAC, and subsequently purified according to modified methods described by Rogalski and Janusz (16).

Preparation offungal ex-LAC.Chromatography was performed using a chromatographic fast protein liquid chromatography system (BioLogic ${ }^{\mathrm{TM}}$ Low-Pressure Liquid Chromatography System; Bio-Rad Laboratories, Inc., Hercules, CA, USA). The supernatant of culture fluid that was concentrated on the aforementioned Pellicon 2 Mini ultrafiltration system was next loaded on a diethylaminoethyl cellulose (DEAE)-Sepharose column of $2.5 \times 15.0 \mathrm{~cm}$ (GE Healthcare Life Sciences, Chalfont, UK), which was pre-equilibrated with $20 \mathrm{mM}$ Tris- $\mathrm{HCl}$ buffer (Sigma-Aldrich), pH 6.5. Proteins were eluted using a 0.1-0.5 M linear gradient of $\mathrm{NaCl}$ (Sigma-Aldrich) at a flow rate of $1 \mathrm{ml} / \mathrm{min}$. The fraction containing LAC activity was collected and desalted on a Sephadex G-50 column of $5.0 \times 20.0 \mathrm{~cm}$ (GE Healthcare Life Sciences). The purification processes were performed at $4^{\circ} \mathrm{C}$. The semi-pure ex-LAC solution was next lyophilized using FreeZone 12 Liter Console Freeze Dry System (Labconco Corporation, Kansas City, MO, USA).

Cell lines. Human chronic myeloid leukemia in blast crisis (K562) and human multiple myeloma (RPMI 8226) cell lines were acquired from the German Collection of Microorganisms and Cell Cultures, Leibniz-Institute DSMZ (Brunswick, Germany). Human acute promyelocytic leukemia (HL-60) and human $\mathrm{T}$ cell leukemia (Jurkat) cell lines were purchased from the American Type Culture Collection (Manassas, VA, USA). All the cell lines were cultured in RPMI 1640 medium (Biochrom; Merck Millipore, Darmstadt, Germany) supplemented with $10 \%$ fetal bovine serum (Biochrom; Merck Millipore) and 1\% Penicillin-Streptomycin-Neomycin Solution (Sigma-Aldrich), and maintained in a humidified atmosphere with $5 \% \mathrm{CO}_{2}$ at $37^{\circ} \mathrm{C}\left(\mathrm{New}\right.$ Brunswick $^{\mathrm{TM}}$ Galaxy $^{\circledR}$ $170 \mathrm{R} \mathrm{CO}_{2}$ Incubator; Eppendorf).

Peripheral blood samples. Upon obtaining written informed consent, peripheral blood was extracted from 
Table I. Clinical characteristics of patients with chronic lymphocytic leukemia.

\begin{tabular}{lc}
\hline Clinical characteristic & Total patients, $\mathrm{n}(\%)$ \\
\hline $\begin{array}{l}\text { Median age, years (range) } \\
\text { Gender }\end{array}$ & $65(47-82)$ \\
Female & $6(66.67 \%)$ \\
Male & $3(33.33 \%)$ \\
Rai stage & \\
0 & $4(44.44 \%)$ \\
I & $4(44.44 \%)$ \\
II & $1(11.11 \%)$ \\
ZAP-70, cut-off 20\% & \\
Positive & $2(22.22 \%)$ \\
Negative & $2(22.22 \%)$ \\
Not available & $5(55.56 \%)$ \\
CD38, cut-off $30 \%$ & \\
Positive & $4(44.44 \%)$ \\
Negative & $5(55.56 \%)$ \\
IGHV status & \\
Mutated & $3(33.33 \%)$ \\
Not mutated & $4(44.44 \%)$ \\
Not available & $2(22.22 \%)$ \\
Cytogenetics & $3(33.33 \%)$ \\
Del(13q) & $1(11.11 \%)$ \\
Del(17p) & $6(66.67 \%)$ \\
No changes &
\end{tabular}

ZAP-70, zeta-chain-associated protein kinase 70; CD, cluster of differentiation; IGHV, immunoglobulin heavy chain variable region; Del, deletion.

nine patients with CLL, whose clinical characteristics are summarized in Table I. This study was approved by the Ethics Committee of the Medical University of Lublin (Lublin, Poland) (no. KE-0254/116/2012). Peripheral blood mononuclear cells (PBMCs) were isolated using Bicoll Density Centrifugation Media (Biochrom, Berlin, Germany). The viability of cells was $>95 \%$, as determined by trypan blue (Sigma-Aldrich) staining and quantification in a Neubauer chamber (Zeiss AG, Oberkochen, Germany). Immediately following isolation, cells were utilized in a 2,3-bis-(2-methoxy-4-nitro-5-sulfophenyl)-2H-te trazolium-5-carboxanilide (XTT; Sigma-Aldrich) assay.

Ex-LAC activity assay. Ex-LAC activity in the culture supernatant was measured spectrophotometrically at $525 \mathrm{~nm}$ with UV-160A spectrophotometer (Shimadzu Corporation, Tokyo, Japan), using syringaldazine (Sigma-Aldrich) as a substrate (18). Enzyme and substrate blanks were included in the assay. A unit (nkat) of ex-LAC activity was defined as the amount of enzyme catalyzing the production of $1 \mathrm{nmol} / \mathrm{sec}$ of colored product (quinone, $\varepsilon^{\mathrm{M}}=65,000 / \mathrm{M} / \mathrm{cm}$ ) at $25^{\circ} \mathrm{C}$ and $\mathrm{pH}$ 7.4. The enzymatic activity of ex-LAC was expressed as nkat/mg of protein.
Protein concentration. Protein concentrations were determined using the Bradford reagent (Sigma-Aldrich), which is based on the color change of Coomassie brilliant blue G-250 dye in response to various concentrations of protein (the dye binds to primarily basic, especially arginine and aromatic amino acid residues), and bovine serum albumin (Sigma-Aldrich) as a standard (19). Protein concentration was determined following the addition of an acidic dye to the protein solution, and absorbance was measured at a wavelength of $595 \mathrm{~nm}$ using a UV-160A spectrophotometer (Shimadzu Corporation).

XTT assay. The cytotoxic effect of ex-LAC was measured using the In Vitro Toxicology Assay Kit, XTT based (Sigma-Aldrich). All cells were suspended in X-VIVO ${ }^{\text {TM }}$ medium with or without phenol red (Lonza Group Ltd., Basel, Switzerland) and gentamicin (Lonza Group Ltd.). Cell lines were seeded onto 96-well plates (GenoPlast Biochemicals, Rokocin, Poland) at a concentration of $5 \times 10^{4}$ cells $/ 100 \mu \mathrm{l} / \mathrm{well}$. PBMCs obtained from patients with CLL were dispensed at a concentration of $5 \times 10^{5}$ cells $/ 100 \mu \mathrm{l} /$ well. Cells were exposed to different concentrations of ex-LAC ranging from 666.667 to $0.007 \mu \mathrm{g} / \mathrm{ml}$. As a negative control, live cells were used, while as a positive control, cells treated with $0.1 \%$ Triton X-100 (Sigma-Aldrich) were used. XTT $(25 \mu \mathrm{l})$ was added to all samples, prior to be incubated for $48 \mathrm{~h}$ in a humidified atmosphere with $5 \% \mathrm{CO}_{2}$ at $37^{\circ} \mathrm{C}$. Optical densities (OD) were measured at $450 \mathrm{~nm}$, using a background wavelength of $690 \mathrm{~nm}$. OD measurements were performed every $24 \mathrm{~h}$. Each sample was assayed in triplicate, and the entire experiment was performed three times. The results were expressed as half maximal inhibitory concentration $\left(\mathrm{IC}_{50}\right)$, and the percentage of cytotoxicity was calculated as follows:

Cytotoxicity $=\left[1-\left(\mathrm{OD}_{\mathrm{s}}-\mathrm{OD}_{\mathrm{b}}\right) /\left(\mathrm{OD}_{\mathrm{c}}-\mathrm{OD}_{\mathrm{b}}\right)\right] \times 100 \%$,

where $\mathrm{OD}_{\mathrm{s}}$ is the $\mathrm{OD}$ value of the assayed sample, $\mathrm{OD}_{\mathrm{b}}$ is the OD value of the positive control and $\mathrm{OD}_{\mathrm{c}}$ is the $\mathrm{OD}$ value of the live cells used as negative control.

Apoptosis analysis. For apoptosis analysis, Jurkat cells were treated with different concentrations of ex-LAC, and $0.1 \%$ Triton X-100 was added as a positive control. Following $48 \mathrm{~h}$ of incubation, all cells were washed using phosphate-buffered saline (PBS; Biochrom; Merck Millipore), resuspended in a binding buffer (Sigma-Aldrich) and stained with $5 \mu \mathrm{l}$ Annexin V-fluorescein isothiocyanate (FITC) and $10 \mu \mathrm{l}$ propidium iodide (PI), according to the manufacturer's protocol of the Annexin V-FITC Apoptosis Detection Kit (Sigma-Aldrich). Cells were incubated for $10 \mathrm{~min}$ in the dark, and immediately analyzed with FACSCalibur ${ }^{\mathrm{TM}}$ (BD Biosciences, San Jose, CA, USA). Live cells served as a negative control.

Visualization of Jurkat and RPMI 8226 cells using fluorescence and scanning electron microscopy (SEM). Jurkat and RPMI 8226 cells were incubated with ex-LAC for 48 h. Following incubation, all cells were washed with PBS, resuspended in a binding buffer and stained with $5 \mu 1$ Annexin V-FITC and $10 \mu \mathrm{l}$ PI, which were provided in the Annexin V-FITC Apoptosis Detection Kit. Cells subjected to SEM (VEGA3 LM; Tescan, Brno, Czech Republic) were pre-treated with $2.5 \%(\mathrm{v} / \mathrm{v})$ glutaraldehyde (Sigma-Aldrich) for $2 \mathrm{~h}$ and $1 \%$ osmium tetroxide (Sigma-Aldrich) for $30 \mathrm{~min}$. 
A

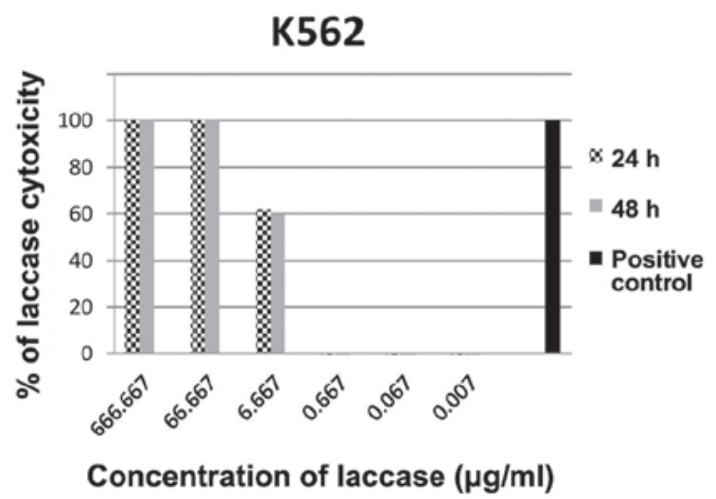

C

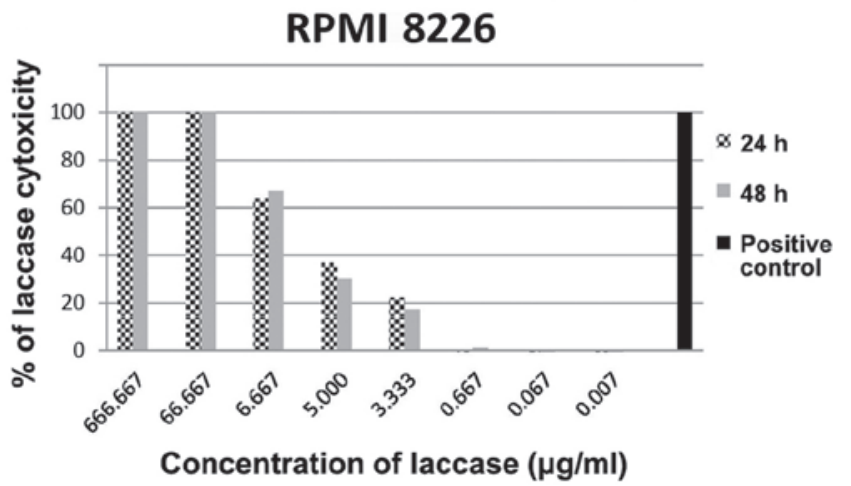

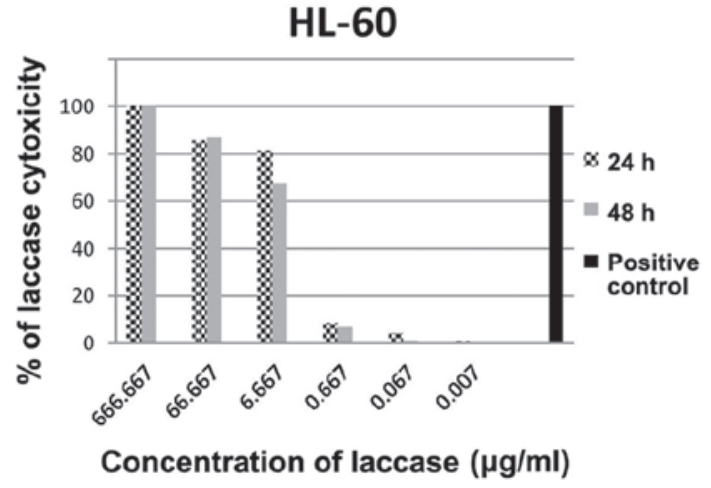

D

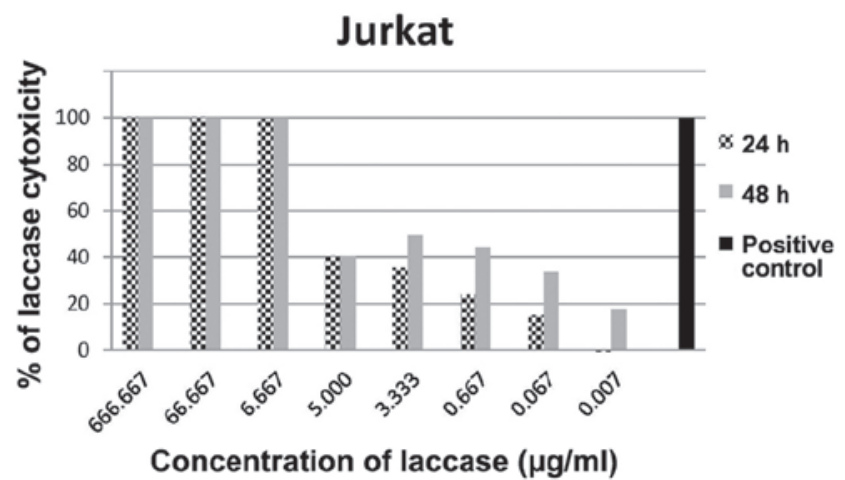

Figure 1. Cytotoxic effects of extracellular laccase on (A) K562, (B) HL-60, (C) RPMI 8226 and (D) Jurkat cell lines. The percentage of cytotoxicity with respect to the control was assessed by 2,3-bis-(2-methoxy-4-nitro-5-sulfophenyl)-2H-tetrazolium-5-carboxanilide assay.

The osmium-fixed cells were subsequently dehydrated using a series of graded ethanol solutions (Sigma-Aldrich) ranging from $10 \%$ to absolute ethanol, followed by air drying at room temperature and coating with gold (Sigma-Aldrich). Magnification $\times 5,000$ was used to observe the cells.

\section{Results}

C. unicolor ex-LAC preparation demonstrates enzymatic activity. Ex-LAC was isolated and partially purified from the idiophasic cultures of $C$. unicolor according to the method previously published by Rogalski and Janusz (16). Purification of $C$. unicolor ex-LAC was performed using ion exchange chromatography on DEAE-Sepharose and Sephadex G-50 columns. The enzyme isoforms Ia1, Ia2, Ib and IIa1 were recovered with a 65-92-fold increase in specific activity and a yield of 6.7, 27.5, 9.7 and $21.0 \%$, respectively. The isoelectric points were in the range of 4.7-4.2 and the carbohydrate content in the purified enzymes was between 1.6 and $3.5 \%$ (16). A total of $1 \mathrm{mg}$ lyophilized ex-LAC isoform mixture dissolved in $1 \mathrm{ml}$ Milli-Q water (EMD Millipore) possessed an activity of $1,150,110 \mathrm{nkat}$ and a protein concentration of $329 \mu \mathrm{g} / \mathrm{ml}$.

Cytotoxicity of C. unicolor ex-LAC on the K562 cell line increases with concentration. To evaluate the cytotoxic effect of ex-LAC on cell lines, cells were treated with a range of concentrations of ex-LAC $(666.667,66.667,6.667,0.667$, 0.067 and $0.007 \mu \mathrm{g} / \mathrm{ml}$ ) for 24 and $48 \mathrm{~h}$, and XTT assays were subsequently performed. The results indicated that the cytotoxicity of ex-LAC on K562 cells increased with concentration (Fig. 1A). Cytotoxicity of $100.00 \%$ against K562 cells was observed following 24 and $48 \mathrm{~h}$ of incubation with 666.667 and $66.667 \mu \mathrm{g} / \mathrm{ml}$ ex-LAC. At a concentration of $6.667 \mu \mathrm{g} / \mathrm{ml}$, the cytotoxic effect of ex-LAC on K562 cells following $24 \mathrm{~h}$ of incubation was $61.78 \%$, and following $48 \mathrm{~h}$ of incubation the cytotoxic effect was $59.80 \%$. No cytotoxic effect was detected on K562 cells following 24 and 48 h of incubation with $0.667,0.067$ and $0.007 \mu \mathrm{g} / \mathrm{ml} \mathrm{C}$. unicolor ex-LAC. The $\mathrm{IC}_{50}$ values of ex-LAC on K562 cells following 24 and $48 \mathrm{~h}$ of treatment were 0.8 and $1.0 \mu \mathrm{g} / \mathrm{ml}$, respectively, as determined by XTT assay.

Concentration-dependent cytotoxic activity of $C$. unicolor ex-LAC is observed in the HL-60 cell line. The cytotoxicity of various concentrations of ex-LAC on HL-60 cells was established using an XTT assay. Following $24 \mathrm{~h}$ of incubation of HL-60 cells with 666.667, 66.667, 6.667, 0.667, 0.067 and $0.007 \mu \mathrm{g} / \mathrm{ml}$ ex-LAC, the percentage of cytotoxicity observed was $100.00,85.63,81.55,8.53,4.39$ and $1.11 \%$, respectively (Fig. 1B). The $\mathrm{IC}_{50}$ value corresponding to 24-h treatment was $0.5 \mu \mathrm{g} / \mathrm{ml}$. Similar results were obtained following $48 \mathrm{~h}$ of HL-60 incubation with ex-LAC. A total of $100.00 \%$ cytotoxicity was observed following incubation with $666.667 \mu \mathrm{g} / \mathrm{ml}$ ex-LAC for $48 \mathrm{~h}, 87.00 \%$ following incubation with $66.667 \mu \mathrm{g} / \mathrm{ml}$ and $67.51 \%$ following incubation with $6.667 \mu \mathrm{g} / \mathrm{ml}$ ex-LAC. Cytotoxicity of $6.94,1.34$ and $0.32 \%$ was observed following $48 \mathrm{~h}$ of incubation with $0.667,0.067$ and $0.007 \mu \mathrm{g} / \mathrm{ml}$ ex-LAC, respectively (Fig. 1B). Following $48 \mathrm{~h}$ 
Table II. Percentage of live, apoptotic and necrotic Jurkat cells following 48-h treatment with Cerrena unicolor ex-LAC, as determined by flow cytometry using Annexin V and propidium iodide staining.

\begin{tabular}{lccc}
\hline Concentration of ex-LAC, $\mu \mathrm{g} / \mathrm{ml}$ & Live cells, $\%$ & Apoptotic cells, $\%$ & Necrotic cells, $\%$ \\
\hline 666.667 & 2.20 & 95.67 & 2.13 \\
66.667 & 3.25 & 95.87 & 0.88 \\
6.667 & 0.82 & 98.00 & 1.18 \\
5.000 & 1.24 & 97.05 & 1.71 \\
3.333 & 1.65 & 96.76 & 1.59 \\
0.667 & 0.68 & 98.90 & 0.42 \\
0.067 & 7.95 & 90.24 & 1.81 \\
0.007 & 8.86 & 88.98 & 2.16 \\
Control & 99.93 & 0.05 & 0.02 \\
\hline
\end{tabular}

ex-LAC, extracellular laccase.

of treatment, the $\mathrm{IC}_{50}$ value of ex-LAC on HL-60 cells was $0.9 \mu \mathrm{g} / \mathrm{ml}$.

C. unicolor ex-LAC decreases viability of the RPMI 8226 cell line. The RPMI 8226 cell line was incubated with a series of dilutions of ex-LAC, and the cytotoxic effect caused by ex-LAC in these cells was also observed to be dose-dependent (Fig. 1C). Following 24- and 48-h treatment of cells with 666.667 and $66.667 \mu \mathrm{g} / \mathrm{ml}$ ex-LAC, $100.00 \%$ cytotoxicity was observed, while $6.667 \mu \mathrm{g} / \mathrm{ml}$ ex-LAC achieved 63.84 and $66.96 \%$ cytotoxicity following 24 and $48 \mathrm{~h}$ of incubation, respectively. Cytotoxicity of 36.77 and $30.20 \%$ was observed following treatment with $5.000 \mu \mathrm{g} / \mathrm{ml}$ ex-LAC for 24 and $48 \mathrm{~h}$, respectively. Following 24 and $48 \mathrm{~h}$ of incubation with $3.333 \mu \mathrm{g} / \mathrm{ml}$ ex-LAC, the observed cytotoxicity on RPMI 8226 cells was 21.97 and $17.59 \%$, respectively. Cytotoxicity of $1.03 \%$ was noted following $48 \mathrm{~h}$ of treatment with $0.667 \mu \mathrm{g} / \mathrm{ml}$ ex-LAC. By contrast, no effect was observed following $24 \mathrm{~h}$ of incubation with $0.667 \mu \mathrm{g} / \mathrm{ml}$ ex-LAC. Similarly, no decrease in RPMI 8226 cell viability was observed following 24 and $48 \mathrm{~h}$ of incubation with 0.067 and $0.007 \mu \mathrm{g} / \mathrm{ml}$ ex-LAC. The $\mathrm{IC}_{50}$ values obtained following 24- and 48-h treatment with ex-LAC were 0.9 and $1.1 \mu \mathrm{g} / \mathrm{ml}$, respectively. The $\mathrm{IC}_{50}$ values following 24- and 48-h treatment with ex-LAC were similar for all cell lines used (K562, 0.8 and $1.0 \mu \mathrm{g} / \mathrm{ml}$; HL-60, 0.5 and $0.9 \mu \mathrm{g} / \mathrm{ml}$; RPMI8226, 0.9 and $1.1 \mu \mathrm{g} / \mathrm{ml}$; and Jurkat, 0.8 and $0.4 \mu \mathrm{g} / \mathrm{ml}$ ). The differences in $\mathrm{IC}_{50}$ values observed result from the fact that each cell line originates from a different neoplasm and different cell lineages. Jurkat cells are derived from a human $\mathrm{T}$ cell leukemia line and $\mathrm{T}$ cells are considered the most treatment resistant cell type (20).

Cytotoxic activity of $C$. unicolor ex-LAC is observed in the Jurkat cell line. The cytotoxic activity of ex-LAC was additionally investigated in the Jurkat cell line via XTT assay (Fig. 1D). Following $24 \mathrm{~h}$ of incubation with 666.667 and $66.667 \mu \mathrm{g} / \mathrm{ml}$ ex-LAC, $100.00 \%$ cytotoxicity was observed in Jurkat cells. Treatment with $6.667 \mu \mathrm{g} / \mathrm{ml}$ ex-LAC resulted in $99.28 \%$ cytotoxicity, while 24 -h treatment with 5.000 and $3.333 \mu \mathrm{g} / \mathrm{ml}$ ex-LAC resulted in 40.39 and $35.22 \%$ cytotoxicity, respectively. Cytotoxicity of 24.00 and $15.14 \%$ was observed following 24-h incubation with 0.667 and $0.067 \mu \mathrm{g} / \mathrm{ml}$ ex-LAC, respectively. No effect on Jurkat cell viability was observed with a concentration of ex-LAC of $0.007 \mu \mathrm{g} / \mathrm{ml}$. By contrast, incubation with $666.667 \mu \mathrm{g} / \mathrm{ml}$ ex-LAC for $48 \mathrm{~h}$ resulted in $100.00 \%$ cytotoxicity. Similarly, concentrations of 66.667 and $6.667 \mu \mathrm{g} / \mathrm{ml}$ had a cytotoxic effect on Jurkat cells of 99.85 and $100.00 \%$, respectively. Similar results were obtained following $48 \mathrm{~h}$ of incubation with $5.000,3.333$ and $0.667 \mu \mathrm{g} / \mathrm{ml}$ ex-LAC, which achieved cytotoxicities of 40.35, 49.46 and $44.36 \%$, respectively. Jurkat cells treated with 0.067 and $0.007 \mu \mathrm{g} / \mathrm{ml}$ ex-LAC for $48 \mathrm{~h}$ exhibited a percentage of cell death of 33.80 and $17.91 \%$, respectively. The $\mathrm{IC}_{50}$ values for 24- and 48-h incubation with ex-LAC were 0.8 and $0.4 \mu \mathrm{g} / \mathrm{ml}$, respectively.

C. unicolor ex-LAC induces morphological changes in the RPMI 8226 cell line. Morphological changes in RPMI 8226 cells following $48 \mathrm{~h}$ of treatment with various concentrations of ex-LAC were observed under fluorescence microscopy and SEM (Fig. 2). Contrarily to untreated RPMI 8226 cells, which possessed a regular, oval shape (Fig. 2A), SEM revealed cell volume shrinkage, membrane blebbing and apoptotic body formation in RPMI 8226 cells treated with ex-LAC (Fig. 2B). For apoptosis detection, ex-LAC-treated and untreated cells were stained with Annexin V and PI, and visualized under a fluorescence microscope (E-800; Nikon Corporation, Tokyo, Japan). In comparison with untreated cells (Fig. 2C), cells treated with ex-LAC displayed apoptotic-like changes, including condensation and fragmentation of nuclei, in addition to cytoplasm condensation (Fig. 2D).

Apoptotic changes in the Jurkat cell line are induced by $e x-L A C$. In order to confirm the results obtained by XTT assay, Jurkat cells were analyzed using Annexin V/PI staining and flow cytometry following $48 \mathrm{~h}$ of incubation with ex-LAC (Table II and Fig. 3). Compared with the control, the percentage of live cells (R4) was decreased, and the percentage of apoptotic cells (R3+R5) was increased for all the concentrations of enzyme tested (Table II). The frequency of live and apoptotic cells in the untreated control was 99.93 and $0.05 \%$, respectively (Fig. 3A). At a concentration of $666.667 \mu \mathrm{g} / \mathrm{ml}$, the percentage of live 

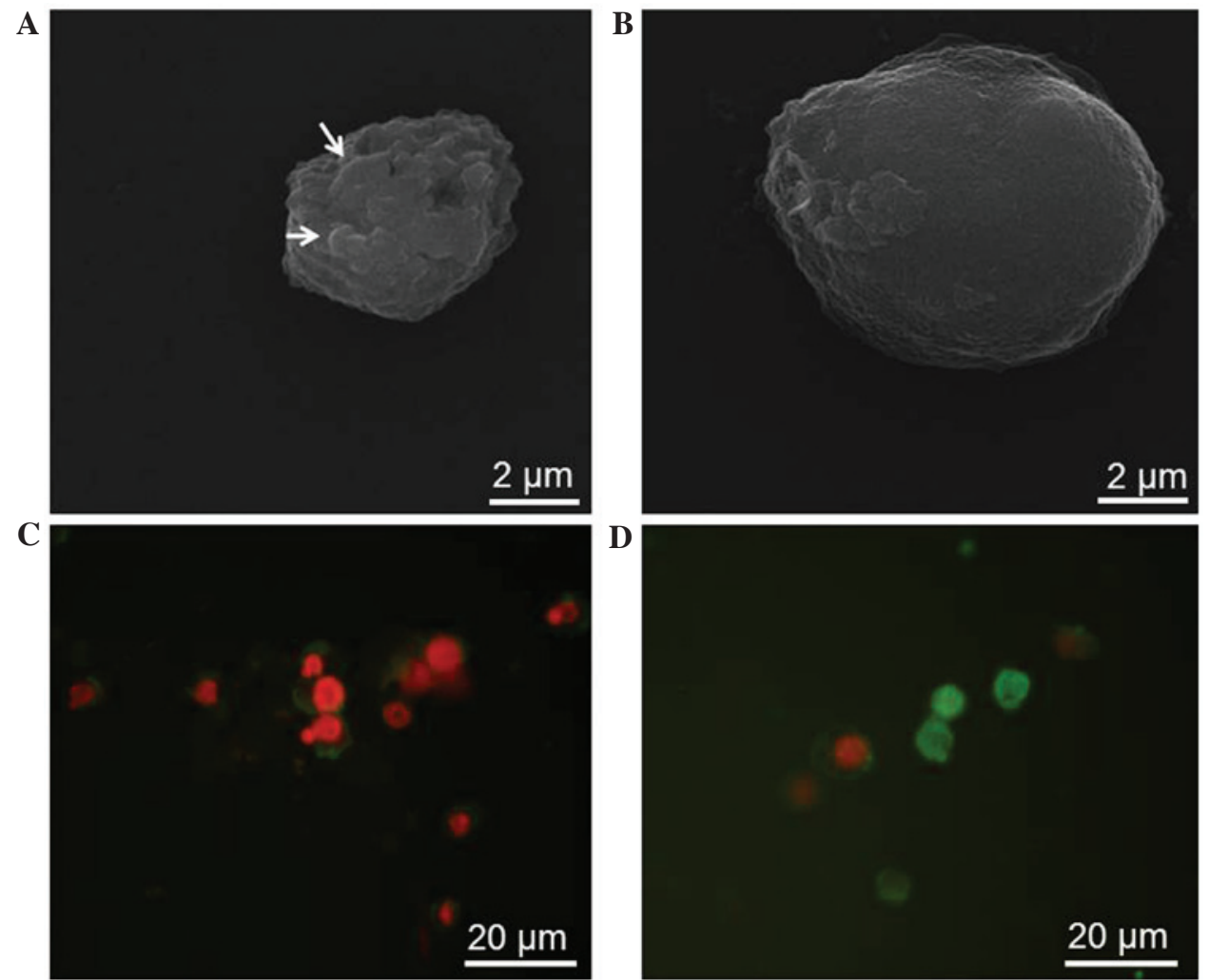

Figure 2. Analysis of the effects of ex-LAC on RPMI 8226 cells following $48 \mathrm{~h}$ of treatment. (A) Changes in cells incubated with $666.667 \mu \mathrm{g} / \mathrm{ml}$ ex-LAC and (B) untreated control cells were visualized by SEM. (C) The effects of treatment with $666.667 \mu \mathrm{g} / \mathrm{ml}$ ex-LAC on RPMI 8226 cells were analyzed by fluorescence microscopy, and compared with (D) untreated cells. Propidium iodide staining (red) indicates apoptotic/necrotic cells. Annexin V-fluorescein isothiocyanate staining (green) indicates viable cells. White arrows indicate apoptotic changes in cells. ex-LAC, extracellular laccase; SEM, scanning electron microscopy.
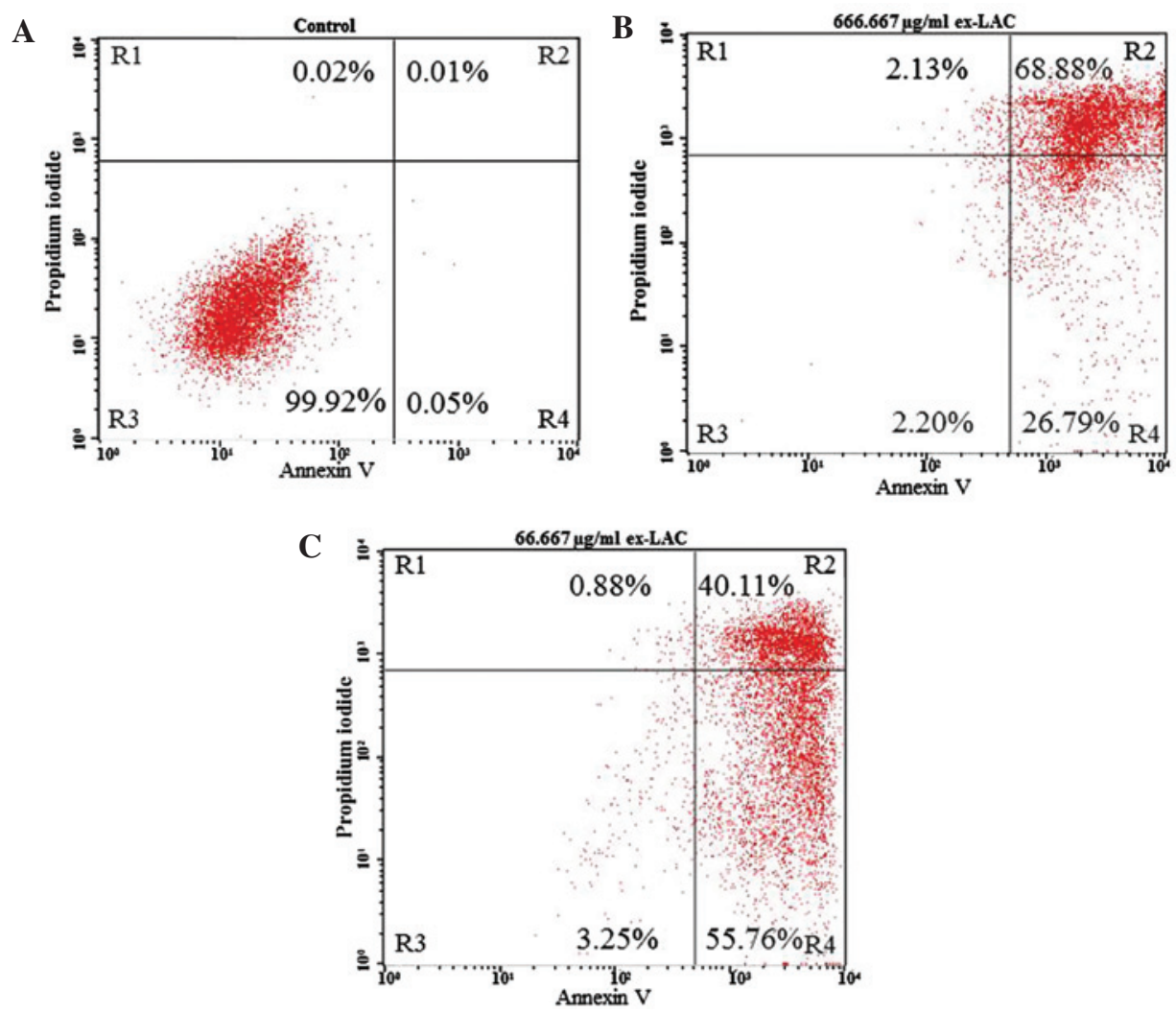

Figure 3. Cytotoxic effect of ex-LAC on Jurkat cells. (A) Control cells. (B) Cells treated with $666.667 \mu \mathrm{g} / \mathrm{ml}$ ex-LAC. (C) Cells treated with $66.667 \mu \mathrm{g} / \mathrm{ml}$ ex-LAC. Cytotoxicity was assessed by staining the cells with Annexin V and PI prior to being subjected to flow cytometry analysis. In each graph, the lower left quadrant (R4) indicates viable cells (Annexin V-PI); the upper left quadrant (R2) represents necrotic cells (Annexin $\mathrm{V}^{-} \mathrm{PI}^{+}$); the lower right quadrant (R5) indicates early apoptotic cells (Annexin $\mathrm{V}^{+} \mathrm{PI}$ ); and the upper right quadrant (R3) represents late apoptotic cells (Annexin $\mathrm{V}^{+} \mathrm{PI}^{+}$). ex-Lac, extracellular laccase; PI, propidium iodide. 
A

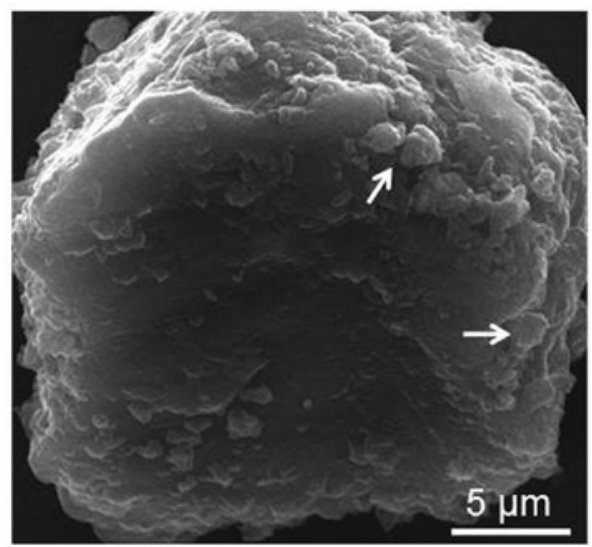

C

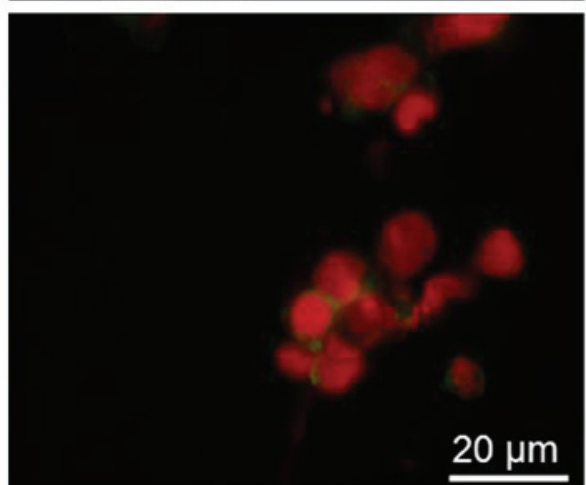

B

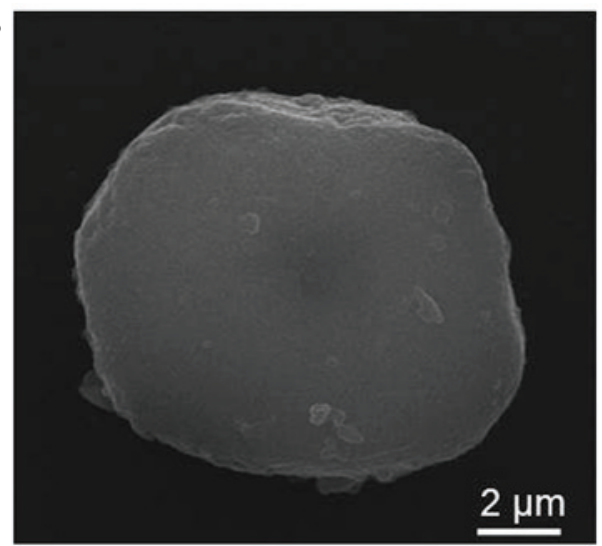

D

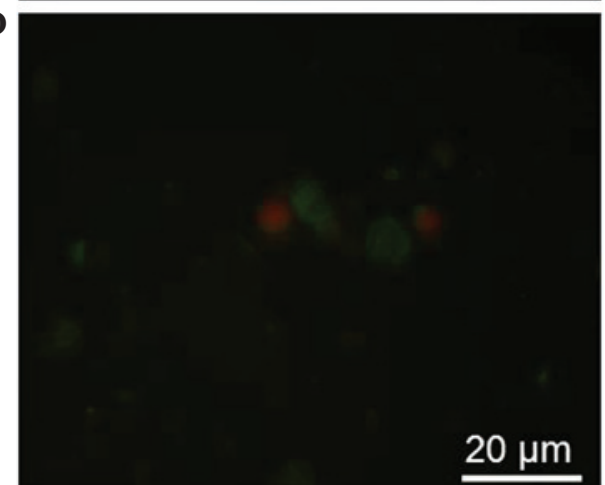

Figure 4. Analysis of the effects of ex-LAC on Jurkat cells following $48 \mathrm{~h}$ of treatment. (A) Changes in cells incubated with $666.667 \mu \mathrm{g} / \mathrm{ml}$ ex-LAC were visualized by SEM.(B) Untreated control cells were visualized by SEM. (C) Fluorescence microscopy analysis of the effects of treatment with $666.667 \mu \mathrm{g} / \mathrm{ml}$ ex-LAC on Jurkat cells, compared with (D) untreated cells. Propidium iodide staining (red) indicates apoptotic/necrotic cells. Annexin V-fluorescein isothiocyanate staining (green) indicates viable cells. White arrows indicate apoptotic changes in cells. ex-LAC, extracellular laccase; SEM, scanning electron microscopy.

vs. apoptotic cells was 2.20 vs. $95.67 \%$ (Fig. 3B), while for a concentration of $66.667 \mu \mathrm{g} / \mathrm{ml}$ these percentages were 3.25 and $95.87 \%$, respectively (Fig. 3C). At a concentration of ex-LAC of $6.667 \mu \mathrm{g} / \mathrm{ml}$ the percentage of live vs. apoptotic cells was 0.82 vs. $98.00 \%$, while it was 1.24 vs. $97.05 \%$ at $5.000 \mu \mathrm{g} / \mathrm{ml}$ ex-LAC. At a concentration of $3.333 \mu \mathrm{g} / \mathrm{ml}$, the percentage of live vs. apoptotic cells were 1.65 vs. $96.76 \%$, while these percentages were 0.68 vs. $98.90 \%, 7.95$ vs. $90.24 \%$ and 8.86 vs $88.98 \%$ for concentrations of ex-LAC of $0.667,0.067$ and $0.007 \mu \mathrm{g} / \mathrm{ml}$, respectively (Table II).

SEM and fluorescence microscopy were used to observe the morphology of control cells and Jurkat cells undergoing treatment with various concentrations of ex-LAC (Fig. 4). Whereas control cells possessed an oval, regular shape (Fig. 4A), SEM observation of Jurkat cells following $48 \mathrm{~h}$ of incubation with ex-LAC revealed several characteristics of apoptosis, including volume shrinkage and apoptotic body formation (Fig. 4B). Ex-LAC-treated and untreated Jurkat cells were stained with Annexin V and PI prior to be observed under fluorescence microscope (E-800; Nikon Corporation). Contrarily to Jurkat control cells (Fig. 4C), cells incubated with ex-LAC for $48 \mathrm{~h}$ displayed nucleus shrinkage and fragmentation, as well as significant cytoplasm condensation (Fig. 4D).

Cytotoxicity of ex-LAC is additionally exerted against primary CLL cells. The cytotoxic activity of $C$. unicolor ex-LAC was also assessed in PBMCs derived from nine patients with CLL via XTT assay (Fig. 5). Based on the results obtained in the established cell lines, three concentrations of enzyme were selected for 24- and 48-h incubation with primary CLL cells. Following $24 \mathrm{~h}$ of incubation with 66.667, 6.667 and $3.333 \mu \mathrm{g} / \mathrm{ml}$ ex-LAC, the median cytotoxic effect observed was $100.00,69.06$ and $42.85 \%$, respectively. Following $48 \mathrm{~h}$ of incubation with $66.667,6.667$ and $3.333 \mu \mathrm{g} / \mathrm{ml}$ ex-LAC, a median cytotoxicity of $100.00,75.99$ and $70.26 \%$ was observed, respectively. The $\mathrm{IC}_{50}$ values of ex-LAC on CLL cells were 0.7 and $0.9 \mu \mathrm{g} / \mathrm{ml}$ following 24 and $48 \mathrm{~h}$ of incubation, respectively.

\section{Discussion}

It has been reported that $C$. unicolor may be a source of active ex-LAC (21). Thus, we hypothesize that $C$. unicolor may be exploited to produce high amounts of this biologically active substance with pharmacological potential. The characterization of $C$. unicolor ex-LAC isoforms has been previously described (22). In the present study, the enzyme isoforms Ia1, Ia2, Ib and IIa1 were recovered with a 65-92-fold increase in specific activity and a yield of 6.7, 27.5, 9.7 and $21.0 \%$, respectively. The isoelectric points were in the range of 4.7-4.2, and the carbohydrate content in the purified enzymes was $1.6-3.5 \%$. The specific activity of this isoform mixture was $3,495.4 \mathrm{nkat} / \mathrm{mg}$ of protein. In comparison with a number of alternative sources of ex-LAC, $C$. unicolor produces the enzyme with high activity without requiring additional supplementation such as aromatic compounds $(21,23)$.

C. unicolor ex-LAC is currently utilized in biodegradation, bioremediation, delignification and decolorization 


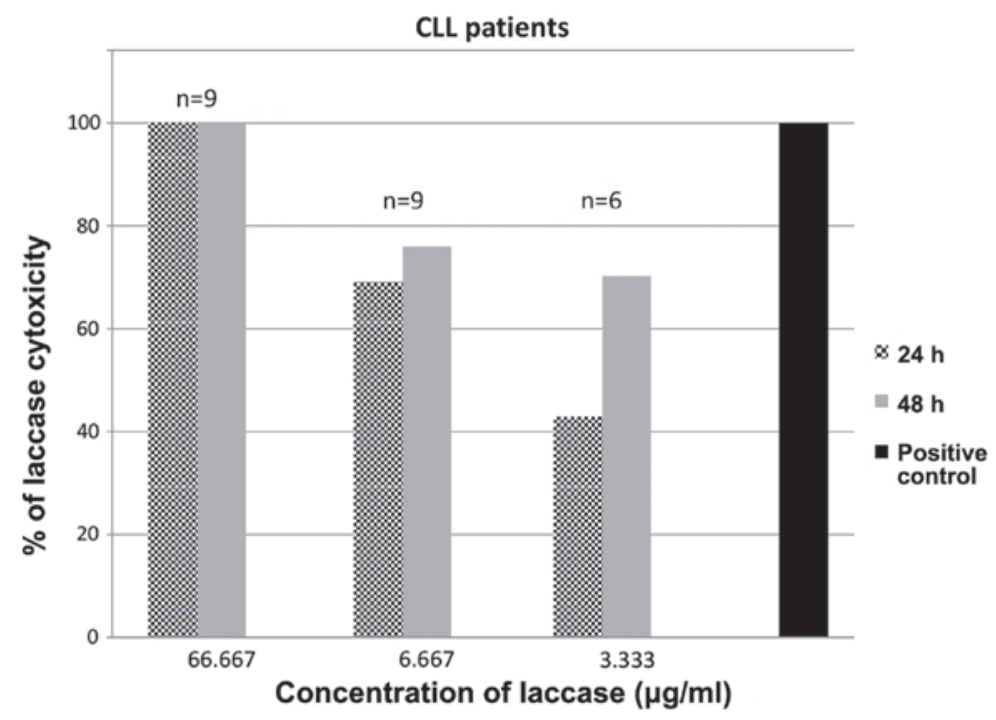

Figure 5. Cytotoxic activity of extracellular laccase on peripheral blood mononuclear cells of patients with chronic lymphocytic leukemia. The percentage of cytotoxicity with respect to the control was assessed by 2,3-bis-(2-methoxy-4-nitro-5-sulfophenyl)-2H-tetrazolium-5-carboxanilide assay.

processes (15). However, to the best of our knowledge, there are no reports to date regarding its anti-leukemic activity. In the present study, it was identified that ex-LAC purified from C. unicolor possessed cytotoxic activity against several hematological malignancies and primary CLL cells using an XTT assay, and these findings were confirmed by apoptosis analysis using flow cytometry, and additionally visualized under SEM and fluorescence microscopy.

Anticancer properties have been reported for several fungal extracts, including Funalia trogii $(7,8)$. Unyayar et al $(8)$ measured the inhibition of growth of the HeLa human cervical cancer cell line and normal fibroblasts following $96 \mathrm{~h}$ of treatment with $F$. trogii. The observed growth inhibition on HeLa cells was $27.2 \%$ for $1 \mu \mathrm{l} F$. trogii extract, $39.7 \%$ for $3 \mu \mathrm{l}, 56.1 \%$ following treatment with $5 \mu 1,59.5 \%$ in the presence of $7 \mu \mathrm{l}$ extract and $71.5 \%$ following incubation with $10 \mu 1$ extract, as evaluated by methyl thiazolyl tetrazolium assay (8). F. trogii extract contains LAC, glutathione reductase and peroxidase, which have been documented to be actively involved in cytotoxicity (8). Rashid et al (7) additionally confirmed the antitumor activity of $F$. trogii extract against the HMEC-1 human microvascular endothelial cell line using a trypan blue exclusion assay (7). The highest toxicity observed in the assay corresponded to $96-\mathrm{h}$ treatment with $2.5 \mathrm{mg} / \mathrm{ml}$ extract, while no toxicity was observed towards fibroblasts and non-proliferating cells under those conditions. The results of the XTT assay performed in the present study indicated that C. unicolor ex-LAC induced cytotoxicity on HL-60, K562, RPMI 8226, Jurkat and primary CLL cells in a dose-dependent manner. The antitumor properties of LAC and peroxidase identified in F. trogii are due to the presence of natural quinone substances produced by the action of these enzymes on a lignin substrate (8). Since all tumor cells are rich in quinones and quinone-like molecules, extracts containing LACs and/or peroxidases are able to selectively convert these molecules into toxic substances that cause apoptosis of cells (8). The pro-oxidative and antibacterial properties of ex-LAC from $C$. unicolor have been previously described (24). In that study, the potential of ex-LAC for production of reactive oxygen species was investigated chemiluminometrically, and a marked pro-oxidative action of the enzyme was identified (24). Estimation of ex-LAC toxicity using a Microtox ${ }^{\circledR}$ detection system demonstrated that the exposure of the marine bacterium Vibrio fischeri to ex-LAC caused 38 and $51 \%$ cell damage following 5 and 15 min of incubation, respectively (24). Ex-LAC has also been reported to be effective against Escherichia coli (24). The apoptosis analysis of ex-LAC extracted from $C$. unicolor conducted in the present study additionally demonstrated apoptosis of Jurkat cells in the presence of various concentrations of ex-LAC, compared with untreated control cells. Apoptotic changes in Jurkat and RMPI 8226 cells caused by $C$. unicolor ex-LAC were also observed under SEM and fluorescence microscopy, thus confirming the above findings.

Lau et al (25) and Unyayar et al (8) have independently documented the cytotoxic activity of Coriolus versicolor extracts. Lau et al (25) observed significant dose-dependent inhibitory effects on the proliferation of the Raji human Burkitt's lymphoma B-cell line and the NB-4 and HL-60 human acute promyelocytic leukemia cell lines treated with $C$. versicolor extract. In that study, $>90 \%$ inhibition was detected following $72 \mathrm{~h}$ of treatment. For the Raji lymphoma cell line, the $\mathrm{IC}_{50}$ value of $C$. versicolor extract was $253.8 \mu \mathrm{g} / \mathrm{ml}$, while for the NB-4 and HL-60 cell lines, the $\mathrm{IC}_{50}$ values were 269.3 and $147.3 \mu \mathrm{g} / \mathrm{ml}$, respectively. The results of the present study revealed that $C$. unicolor ex-LAC was able to inhibit proliferation of human leukemic cell lines in a dose-dependent manner at lower dosages than those documented by Lau et al (25), since the $\mathrm{IC}_{50}$ values following $48 \mathrm{~h}$ of treatment were 0.9 , 0.4, 1.1 and $1.0 \mu \mathrm{g} / \mathrm{ml}$ for HL-60, Jurkat, RPMI 8226 and K562 cells, respectively. Furthermore, the inhibitory effect of $C$. versicolor extracts on the HeLa cell line demonstrated by Unyayar et al (8) was lower than the activity of $C$. unicolor ex-LAC identified in the present study, since $1 \mu \mathrm{l} C$. versicolor extract caused $27.5 \%$ growth inhibition in HeLa cells, and the maximum inhibition observed was $45.5 \%$ following treatment with $10 \mu l$ extract (8). The results of the present study indicated 
an inhibitory effect of $C$. unicolor ex-LAC of $\sim 100.00 \%$ at a concentration of $666.667 \mu \mathrm{g} / \mathrm{ml}$ on all the cell lines tested.

Anti-leukemic activity of agaritine, a $\beta$-glucan isolated from Agaricus blazei, was reported by Endo et al (26). In that study, the 2-(2-methoxy-4-nitrophenyl)-3-(4-nitrophenyl)-5-(2 ,4-disulfophenyl)-2H-tetrazolium assay was used to evaluate the inhibitory effect of agaritine from A. blazei on the U937 human leukemic monocyte lymphoma, MOLT-4 human acute lymphoblastic leukemia, HL-60 and K652 cell lines following $48 \mathrm{~h}$ of treatment. The authors observed that the viability of all the cell lines tested decreased with increasing concentrations of agaritine. Agaritine suppressed cell growth in U937, MOLT-4, HL-60 and K562 cells with an $\mathrm{IC}_{50}$ value of 2.7, 9.4, 13.0 and $16.0 \mu \mathrm{g} / \mathrm{ml}$, respectively (26). By contrast, in the present study, following $48 \mathrm{~h}$ of incubation of HL-60 and $\mathrm{K} 562$ cells with $C$. unicolor ex-LAC, the $\mathrm{IC}_{50}$ values measured ( 0.9 and $1.0 \mu \mathrm{g} / \mathrm{ml}$, respectively) were lower than those reported by Endo et al (26), indicating increased activity of $C$. unicolor ex-LAC compared with A. blazei agaritine.

Chen et al (27) investigated the antitumor and immunomodulatory effects of PCP-3A, a non-lectin glycoprotein extracted from the mushroom Pleurotus citrinopileatus (27). Trypan blue exclusion assay revealed 37-64\% growth inhibition of U937 cells following $72 \mathrm{~h}$ of incubation with $25 \mu \mathrm{g} / \mathrm{ml}$ PCP-3A. In addition, P. citrinopileatus PCP-3A was able to stimulate the secretion of tumor necrosis factor $\alpha$, interleukin- 2 and interferon- $\gamma$ by CD $4{ }^{+} \mathrm{T}$ cells, which indirectly suppressed the growth of U937 cells, indicating that PCP-3A possessed antitumor and immunomodulatory activities (27). By contrast, $C$. unicolor ex-LAC inhibited the growth of K562, Jurkat and RPMI 8226 cells by $100.00 \%$ at a concentration of $66.6667 \mu \mathrm{g} / \mathrm{ml}$, while $87.00 \%$ cytotoxicity was observed in the HL-60 cell line at a concentration of $66.667 \mu \mathrm{g} / \mathrm{ml}$, as assessed by XTT assay in the present study. Furthermore, $6.667 \mu \mathrm{g} / \mathrm{ml}$ C. unicolor ex-LAC exhibited a higher cytotoxic rate against the tested cell lines than $25 \mu \mathrm{g} / \mathrm{ml} P$. citrinopileatus PCP-3A, with cytotoxic rates of $67.51,59.80,100.00$ and $66.96 \%$ for HL-60, K562, Jurkat and RPMI 8226 cells, respectively. Additionally, C. unicolor ex-LAC was demonstrated to induce apoptosis, which was further confirmed in Jurkat and RPMI 8226 cell lines using flow cytometry and microscopic techniques in the present study.

Tsai et al (28) reported a novel non-lectin glycoprotein (HM-3A) purified from Hypsizygus marmoreus with anti-leukemic activity against the U937 cell line (28). The antiproliferative effect of HM-3A increased with concentration. As demonstrated by trypan blue exclusion assay, HM-3A induced cytotoxicity against U937 cells at concentrations ranged between 12.5 and $100.0 \mu \mathrm{g} / \mathrm{ml}$, following treatment for 24-72 h. At $100.0 \mu \mathrm{g} / \mathrm{ml}, \mathrm{HM}-3 \mathrm{~A}$ led to $96.2 \%$ growth inhibition of U937 cells within $72 \mathrm{~h}$ (28). Similar cytotoxic rates were observed in the current study, as $100.00 \%$ cytotoxicity was achieved at concentrations of 666.667 and $66.667 \mu \mathrm{g} / \mathrm{ml} \mathrm{C}$. unicolor ex-LAC in K562, Jurkat and RPMI 8226 cell lines. In HL-60 cells, growth inhibition at 666.667 and $66.667 \mu \mathrm{g} / \mathrm{ml} \mathrm{C}$. unicolor ex-LAC was 100.00 and $87.00 \%$, respectively. Therefore, the results of the present study indicated that $C$. unicolor ex-LAC possessed similar anti-leukemic activity to $H$. marmoreus HM-3A.

PNAP, a novel protein with antitumor activity towards HeLa cells and the MCF7 breast cancer cell line, was isolated from Pholiota nameko by Zhang et al (29). The results of a trypan blue exclusion assay conducted by these authors revealed dose-dependent antiproliferative effects of PNAP following $24 \mathrm{~h}$ of treatment, with an $\mathrm{IC}_{50}$ value of $9.97 \mu \mathrm{M}$ for MCF7 cells and $12.11 \mu \mathrm{M}$ for HeLa cells. The authors observed that the cytotoxic effect of PNAP on cancer cell lines was significantly increased, compared with the effect on normal cells (29). In the present study, the $\mathrm{IC}_{50}$ values observed following $24 \mathrm{~h}$ of incubation with $C$. unicolor ex-LAC were $0.5,0.8,0.9,0.8$ and $0.7 \mu \mathrm{g} / \mathrm{ml}$ for HL-60, Jurkat, RPMI 8226, K562 and CLL primary cells, respectively. Flow cytometric analysis of apoptosis performed by Zhang et al (29) following $48 \mathrm{~h}$ of incubation of MCF7 cells with 5, 10 and $15 \mu \mathrm{M}$ PNAP revealed the presence of $5.29,10.05$ and $22.88 \%$ apoptotic cells, respectively, whilst the apoptotic rate in non-treated cells was $3.23 \%$. By contrast, in the present study, apoptotic rates ranging from 88.98 to $98.90 \%$ were observed in Jurkat cells following $48 \mathrm{~h}$ of ex-LAC treatment, depending on the concentration of ex-LAC used. Furthermore, Zhang et al (29) measured the accumulation of mitochondrial cytochrome $c$ release into the cytosol, and observed that the cytosol from untreated cells contained low amounts of cytochrome $c$, in contrast to MCF7 cells incubated with PNAP, where cytochrome $c$ was significantly accumulated. Similarly, reduced levels of cytochrome $c$ in the mitochondrial fraction were also detected. Release of cytochrome $c$ resulted in the activation of caspase-mediated apoptosis (29). In the present study, SEM and fluorescence microscopy images of ex-LAC-treated Jurkat and RPMI 8226 cells also indicated apoptosis involving cell volume and nucleus shrinkage, apoptotic body formation and fragmentation, as well as significant cytoplasm condensation.

To the best of our knowledge, a limited number of LACs of fungal origin with anti-malignant properties have been described thus far. Zhang et al (29) reported antiproliferative activity of Clitocybe maxima LAC against HepG2 and MCF7 hepatocellular carcinoma cells, and inhibitory activity towards human immunodeficiency virus (HIV)-1 reverse transcriptase (30). At concentrations of 2.5, 5.0, 10.0 and $20.0 \mu \mathrm{M}$, purified LAC from $C$. maxima inhibited the proliferation of HepG2 cells by 9.1, 20.4, 43.0 and $80.5 \%$, respectively, and inhibited cell growth in MCF7 cells by 40.2, 75.3, 90.2 and 95.4\%, respectively. The $\mathrm{IC}_{50}$ values against HepG2 and MCF7 cells were 12.3 and $3.0 \mu \mathrm{M}$, respectively. The authors observed that $C$. maxima LAC reduced the activity of HIV-1 reverse transcriptase with an $\mathrm{IC}_{50}$ value of $14.4 \mu \mathrm{M}$, and the percentage of inhibition of $\mathrm{HIV}-1$ reverse transcriptase activity at 5, 10 and $20 \mu \mathrm{M} \mathrm{C}$. maxima LAC was 13.7, 35.1 and 70.4\%, respectively. Zhang et al (31) purified LAC from the white-rot fungus Abortiporus biennis and proved its antitumor activity against HepG2 and MCF7 cells, as well as observing its inhibitory activity against HIV-1 reverse transcriptase, achieving $\mathrm{IC}_{50}$ values of 12.5, 6.7 and $9.2 \mu \mathrm{M}$, respectively (31). Hu et al (32) demonstrated that LAC extracted from the fruiting bodies of Agrocybe cylindracea species possessed antiproliferative activity against MCF7 and HepG2 cell lines (32). The authors noted that $A$. cylindracea LAC additionally possessed HIV-1 reverse transcriptase inhibitory activity, with percentages of inhibition at 3.2, 8.0 and $20.0 \mu \mathrm{M}$ of $15.7,40.2$ and $62.5 \%$, respectively, and a calculated $\mathrm{IC}_{50}$ value of $12.7 \mu \mathrm{M}$. The cytotoxicity of A. cylindracea LAC towards HepG2 cells was 
7.8, 30.2, 46.4 and 78.5\% at concentrations of 1.2, 2.5, 5.0 and $10.0 \mu \mathrm{M}$, respectively, with an $\mathrm{IC}_{50}$ value of $5.6 \mu \mathrm{M}$. In the case of MCF7 cells, the $\mathrm{IC}_{50}$ value was $6.5 \mu \mathrm{M}$, and the percentage of inhibition was 7.2, 22.7, 41.3 and $70.6 \%$ at concentrations of $1.2,2.5,5.0$ and $10.0 \mu \mathrm{M}$, respectively (32). In the present study, ex-LAC isolated from $C$. unicolor induced a higher cytotoxic effect towards HL-60, Jurkat, RPMI 8226 and K562 cells than A. cylindracea LAC did in the above previous study, since C. unicolor LAC demonstrated $\mathrm{IC}_{50}$ values of $0.5(0.01 \mu \mathrm{M})$, $0.8(0.014 \mu \mathrm{M})$ and $0.9(0.016 \mu \mathrm{M}) \mu \mathrm{g} / \mathrm{ml}$ for HL-60, Jurkat, RPMI 8226 and K562 cells, respectively.

To the best of our knowledge, the present study represents the first report to investigate the anti-leukemic activity of ex-LAC isolated and partially purified from idiophasic cultures of C. unicolor. The present study provided novel data concerning the isolation and chemical characterization of bioactive compounds of the white-rot fungus $C$. unicolor. The cytotoxic effect of ex-LAC extracted from this fungus was demonstrated on HL-60, Jurkat, RPMI 8226 and K562 cell lines, as well as CLL primary cells, using XTT assay. Additional analysis of Jurkat and RPMI 8226 cells revealed that $C$. unicolor ex-LAC was able to induce apoptosis of leukemic cells, even at low concentrations. Compared with other compounds of fungal origin, the $\mathrm{IC}_{50}$ values of $C$. unicolor ex-LAC were reduced, indicating high anti-malignant activity of this enzyme. In conclusion, the results of the present study suggest that C. unicolor ex-LAC should be considered as a novel therapeutic agent for the treatment of hematological malignancies.

\section{Acknowledgements}

The present study was supported by a grant from the Medical University of Lublin (Lublin, Poland) (grant no. DS 462).

\section{References}

1. Hoehn D, Medeiros LJ and Konoplev S: Molecular pathology of chronic lymphocytic leukemia. In: Hematopathology: Genomic mechanisms of neoplastic diseases. Crisan D (ed). Humana Press, New York, pp255-pp291, 2010.

2. Xu Z, Zhang J, Wu S, Zheng Z, Chen Z and Zhan R: Younger patients with chronic lymphocytic leukemia benefit from rituximab treatment: A single center study in China. Oncol Lett 5: 1266-1272, 2013.

3. Ghia P, Ferreri AM and Caligaris-Cappio F: Chronic lymphocytic leukemia. Crit Rev Oncol Hematol 64: 234-246, 2007.

4. Giannopoulos K: Biology and prognosis in chronic lymphocytic leukemia. Acta Haematol Pol 41: 433-440, 2010 (In Polish).

5. Giannopoulos K, Dmoszynska A, Kowal M, Wasik-Szczepanek E, Bojarska-Junak A, Rolinski J, Döhner H, Stilgenbauer S and Bullinger L: Thalidomide exerts distinct molecular antileukemic effects and combined thalidomide/fludarabine therapy is clinically effective in high-risk chronic lymphocytic leukemia. Leukemia 23: 1771-1778, 2009.

6. Patel S and Goyal A: Recent developments in mushrooms as anti-cancer therapeutics: A review. 3 Biotech 2: 1-15, 2012.

7. Rashid S, Unyayar A, Mazmanci MA, McKeown SR, Banat IM and Worthington J: A study of anti-cancer effects of Funalia trogii in vitro and in vivo. Food Chem Toxicol 49: 1477-1483, 2011.

8. Unyayar A, Demirbilek M, Turkoglu M, Celik A, Mazmanci MA, Erkurt EA, Unyayar S, Cekic O and Atacag H: Evaluation of cytotoxic and mutagenic effects of Coriolus versicolor and Funalia trogii extracts on mammalian cells. Drug Chem Toxicol 29: 69-83, 2006.

9. Leatham GF and Stahmann MA: Studies on the laccase of Lentinus edodes: Specificity, localization and association with the development of fruiting bodies. J Gen Microbiol 125: 147-157, 1981.
10. Solomon EI, Sundaram UM and Machonkin TE: Multicopper oxidases and oxygenases. Chem Rev 96: 2563-2606, 1996.

11. Baldrian P: Fungal laccases - occurrence and properties. FEMS Microbiol Rev 30: 215-242, 2006.

12. Abadulla E, Tzanov T, Costa S, Robra KH, Cavaco-Paulo A and Gübitz GM: Decolorization and detoxification of textile dyes with a laccase from Trametes hirsuta. Appl Environ Microbiol 66: 3357-3362, 2000.

13. Telke AA, Ghodake GS, Kalyani DC, Dhanve RS and Govindwar SP: Biochemical characteristics of a textile dye degrading extracellular laccase from a Bacillus sp. ADR. Bioresour Technol 102: 1752-1756, 2011.

14. Janusz G, Rogalski J and Szczodrak J: Increased production of laccase by Cerrena unicolor in submerged liquid cultures. World J Microbiol Biotechnol 23: 1459-1464, 2007.

15. Kucharzyk KH, Janusz G, Karczmarczyk I and Rogalski J: Chemical modifications of laccase from white-rot basidiomycete Cerrena unicolor. Appl Biochem Biotechnol 168: 1989-2003, 2012.

16. Rogalski J and Janusz G: Purification of extracellular laccase from Cerrena unicolor. Prep Biochem Biotechnol 40: 242-255, 2010.

17. Betina V: Differentiation and secondary metabolism in some prokaryotes and fungi. Folia Microbiol (Praha) 40: 51-67, 1995.

18. Leonowicz A and Grzywnowicz K: Quantitative estimation of laccase forms in some white rot fungi using syringaldazine as a substrate. Enzyme Microb Technol 3: 55-58, 1981.

19. Bradford MM: A rapid and sensitive method for the quantitation of microgram quantities of protein utilizing the principle of protein dye binding. Anal Biochem 72: 248-254, 1976.

20. Jabbour E, O'Brien S, Konopleva M and Kantarjian H. New insights into the pathophysiology and therapy of adult acute lymphoblastic leukemia. Cancer 121: 2517-2528, 2015.

21. Leonowicz A, Gianfreda L, Rogalski J, Jaszek M, Luterek J, Wasilewska MW, Malarczyk E, Dawidowicz A, Fink-Boots M, Ginalska G, et al: Appearance of laccase in wood-rotting fungi and its inducibility. J Korean Wood Sci Technol 25: 29-36, 1997.

22. Janusz G, Mazur A, Checinska A, Malek W, Rogalski J and Ohga S: Cloning and characterization of a laccase gene from biotechnologically important basidiomycete Cerrena unicolor. J Fac Agr Kyushu U 57: 41-49, 2012.

23. Majeau JA, Brar SK and Tyagi RD: Laccases for removal of recalcitrant and emerging pollutants. Bioresour Technol 101: 2331-2350, 2010

24. Jaszek M, Osińska-Jaroszuk M, Janusz G, Matuszewska A, Stefaniuk D, Sulej J, Polak J, Ruminowicz M, Grzywnowicz K and Jarosz-Wilkołazka A: New bioactive fungal molecules with high antioxidant and antimicrobial capacity isolated from Cerrena unicolor idiophasic cultures. BioMed Res Int 2013: 497492, 2013.

25. Lau CB, Ho CY, Kim CF, Leung KN, Fung KP, Tse TF, Chan HH and Chow MS: Cytotoxic activities of Coriolus versicolor (Yunzhi) extract on human leukemia and lymphoma cells by induction of apoptosis. Life Sci 75: 797-808, 2004.

26. Endo M, Beppu H, Akiyama H, Wakamatsu K, Ito $S$, Kawamoto Y, Shimpo K, Sumiya T, Koike T and Matsui T: Agaritine purified from Agaricus blazei Murrill exerts anti-tumor activity against leukemic cells. Biochim Biophys Acta 1800: 669-673, 2010.

27. Chen JN, Ma CY, Tsai PF, Wang YT and Wu JS: In vitro antitumor and immunomodulatory effects of the protein PCP-3A from mushroom Pleurotus citrinopileatus. J Agric Food Chem 58: 12117-12122, 2010.

28. Tsai PF, Ma CY and Wu JS: A novel glycoprotein from mushroom Hypsizygus marmoreus (Peck) Bigelow with growth inhibitory effect against human leukemic U937 cells. Food Chem 141: 1252-1258, 2013.

29. Zhang Y, Liu Z, Ng TB, Chen Z, Qiao W and Liu F: Purification and characterization of a novel antitumor protein with antioxidant and deoxyribonuclease activity from edible mushroom Pholiota nameko. Biochimie 99: 28-37, 2014.

30. Zhang GQ, Wang YF, Zhang XQ, Ng TB and Wang HX: Purification and characterization of a novel laccase from the edible mushroom Clitocybe maxima. Process Biochem 45: 627-633, 2010.

31. Zhang GQ, Tian T, Liu YP, Wang HX and Chen QJ: A laccase with anti-proliferative activity against tumor cells from a white root fungus Abortiporus biennis. Process Biochem 46: 2336-2340, 2011

32. Hu DD, Zhang RY, Zhang GQ, Wang HX and Ng TB: A laccase with antiproliferative activity against tumor cells from an edible mushroom, white common Agrocybe cylindracea. Phytomedicine 18: 374-379, 2011. 